\title{
Correlation between quality of life, depression, satisfaction and functionality of older people with HIV
}

\author{
Correlação entre qualidade de vida, depressão, satisfação e funcionalidade das pessoas idosas com HIV \\ Correlación entre calidad de vida, depresión, satisfacción y funcionalidad de personas mayores con VIH
}

$\begin{array}{r}\hline \text { Kydja Milene Souza Torres de Araújo' } \\ \text { ORCID: 0000-0001-5258-8780 } \\ \text { Suelane Renata de Andrade Silva"' } \\ \text { ORCID: 0000-0002-2501-8245 } \\ \text { Daniela de Aquino Freire' } \\ \text { ORCID: 0000-0002-6708-5139 } \\ \text { Márcia Carréra Campos Leal"' } \\ \text { ORCID: 0000-0002-3032-7253 } \\ \text { Ana Paula de Oliveira Marques"'" } \\ \text { ORCID: 0000-0003-0731-8065 } \\ \text { Rosilene Santos Baptistalv } \\ \text { ORCID: 0000-0001-7400-7967 } \\ \text { Antônia Leda Oliveira Silva" } \\ \text { ORCID: 0000-0001-7758-2035 } \\ \hline\end{array}$

'Universidade de Pernambuco. Recife, Pernambuco, Brazil. "Universidade Federal da Paraíba. João Pessoa, Paraíba, Brazil. I"Universidade Federal de Pernambuco. Recife,

Pernambuco, Brazil.

"Universidade Estadual da Paraíba. Campina Grande Paraíba, Brazil.

How to cite this article: Araújo KMST, Silva SRA, Freire DA, Leal MCC, Marques APO, Baptista RS, et al. Correlation between quality of life, depression, satisfaction and functionality of older people with HIV. Rev Bras Enferm. 2021;74(Suppl 2):e20201334. https://doi.org/10.1590/0034-7167-2020-1334

\section{Corresponding author: \\ Kydja Milene Souza Torres de Araújo \\ E-mail: kydjamilleny@hotmail.com

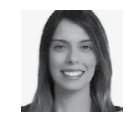

EDITOR IN CHIEF: Antonio José de Almeida Filho ASSOCIATE EDITOR: Alexandre Bansanelli

\begin{abstract}
Objective: To analyze the correlation between the quality of life, depression, life satisfaction, and functional capacity in elderly people living with the Human Immunodeficiency Virus (HIV). Methods: A cross-sectional study developed in reference hospitals for treatment and followup of people with HIV. 241 elderly people participated by applying a questionnaire containing sociodemographic variables, the HIV/AIDS target quality of Life, the Barthel Index, the Life Satisfaction Scale, and the abbreviated version with 15 items of the Yesavage Geriatric Depression Scale. Results: The analyses showed an inverse correlation between the dimensions of the HATQol with depression, a positive correlation in the domain satisfaction with life, and statistically significant, but weak, with functionality. Conclusion: Depression impairs quality of life in all dimensions, while life satisfaction influences this aspect more positively than functional capacity. Descriptors: Quality of Life; Depression; Personal Satisfaction; Aged; HIV.
\end{abstract}

\section{RESUMO}

Objetivo: Analisar a correlação entre qualidade de vida, depressão, satisfação com a vida e capacidade funcional nas pessoas idosas que vivem com o Vírus da Imunodeficiência Humana (HIV). Métodos: estudo de corte transversal, desenvolvido em hospitais de referência para tratamento e acompanhamento de pessoas com HIV. Participaram 241 idosos, mediante a aplicação de um questionário contendo variáveis sociodemográficas, o HIV/AIDS Target Quality of Life, do Índice de Barthel, da Escala de Satisfação com a Vida e da versão abreviada com 15 itens da Escala de Depressão Geriátrica de Yesavage. Resultados: as análises evidenciaram correlação inversa entre as dimensões do HAT-Qol com a depressão, correlação positiva no domínio satisfação com a vida e estatisticamente significante, porém fraca, com a funcionalidade. Conclusão: a depressão prejudica a qualidade de vida em todas as dimensões, enquanto a satisfação com a vida influencia mais positivamente este aspecto do que a capacidade funcional. Descritores: Qualidade de Vida; Depressão; Satisfação Pessoal; Idoso; HIV.

\section{RESUMEN}

Objetivo: Analizar la correlación entre calidad de vida, depresión, satisfacción con la vida y capacidad funcional en personas mayores que conviven con el Virus de Inmunodeficiencia Humana (VIH). Métodos: estudio transversal, desarrollado en hospitales de referencia para el tratamiento y seguimiento de personas con VIH. Participaron 241 personas mayores mediante la aplicación de un cuestionario con variables sociodemográficas, del HIV/AIDS-Target Quality of Life, del Índice de Barthel, de la Escala de Satisfacción con la Vida y la versión abreviada con 15 ítems de la Escala Yesavage para Depresión Geriátrica. Resultados: los análisis mostraron correlación inversa entre las dimensiones del HIV/AIDS-Target Quality of Life y depresión, correlación positiva en el dominio de satisfacción con la vida y estadísticamente significativa, pero débil con funcionalidad. Conclusión: la depresión afecta la calidad de vida en todas las dimensiones, mientras que la satisfacción con la vida influye más positivamente en este aspecto que la capacidad funcional. Descriptores: Calidad de Vida; Depresión; Satisfacción Personal; Anciano; VHI. 


\section{INTRODUCTION}

Infection with the human immunodeficiency virus affects people of all age groups and their transmission occurs through unprotected sexual intercourse, by direct contact with body fluids of an already infected individual, or from mother to child during gestation, childbirth, or breastfeeding ${ }^{(1)}$. In Brazil, individuals between 25 and 39 years of age, of both genders, concentrate the largest number of cases, being more prevalent among men $^{(2)}$. And for being the most populous country in Latin America, concentrates approximately $40 \%$ of new cases $^{(3)}$. In the last ten years, a significant increase in new cases has been identified in male individuals aged 15 to 24 years and in the group of 60 years or older. In women, we observe this increase in those between 15 and 19 years and from 55 years ${ }^{(2)}$.

This increase in cases in individuals from 60 years is a reflection of the demographic transition, which has already caused visible changes in the structure of the population pyramid due to population aging and, consequently, the improvement in the quality of life of the population, and the reduction of mortality and fertility rates. In Brazil, the latter rate was, in 1960, 6.3 children per woman, declining to 4.4 children/woman in the $80 \mathrm{~s}$ and 1.94 in 2010. Currently, the fertility rate in Brazil is 1.7 children/woman, i.e., below the population replacement level of $2.2^{(4)}$ and with a projection of 1.6 children/woman by $2040^{(5)}$.

It is worth noting that in the 80s the main cause of HIV transmission in the elderly was blood, but today the sexual transmission has become the primary source of contagion ${ }^{(6)}$. According to information from the Ministry of Health, from 1980 to 2000, 4,761 cases of HIV were reported in people aged 60 years and from 2001 to 2016, the number reached 28,122 individuals ${ }^{(2)}$.

Given this increasing quantity, HIV in the elderly can be considered a public health problem since this public has a potential risk of contamination by sexual means ${ }^{(7)}$. Sexual health, as well as the practice of sexuality in this population, were not prioritized over the years either in public policies or within the scope of research, which contributed to the strengthening of the stigma related to this theme ${ }^{(8)}$, still so little discussed, perceived and understood by society in general.

In this sense, HIV in the elderly can have great repercussions, as it tends to cause impacts on morality, ethics, and religion ${ }^{(9)}$, with direct reflections on the quality of life, because, in addition to advancing age, imposes the complex coexistence with the stigma of a "disease" that refers to promiscuity ${ }^{(10)}$. This stigma may generate psychological damage by increasing anxious symptoms, feelings of loneliness, the emergence or worsening of depression, dissatisfaction with life, longing for death or suicidal ideation, and low self-esteem ${ }^{(11)}$.

In addition, the aging process may be accompanied by a progressive decline in functional capacity, which may be aggravated as a result of the negative repercussions triggered by HIV infection ${ }^{(12)}$. This set of factors makes it relevant to conduct researches that investigates the process of aging with HIV as a whole, to subsidize the conduct of health professionals during care planning.

\section{OBJECTIVE}

Analyze the correlation between the quality of life, depression, life satisfaction, and functionality in elderly people living with the Human Immunodeficiency Virus (HIV).

\section{METHODS}

\section{Ethical aspects}

This research is linked to the project "Identification of the social and epidemiological profile of the elderly infected with HIV/Aids assisted in reference services," approved by the Research Ethics Committee of the Federal University of Pernambuco. Thus, the research met the predetermined requirements in Resolution No. $466 / 2012$ of the Ministry of Health, regarding the development of scientific research involving human beings. The participants received the Free and Informed Consent Form, through which advised about the research's objectives, the guarantee of anonymity, and the possibility of withdrawing the research at any time and without prejudice if they deemed necessary.

\section{Design, period and place of study}

This is an observational cross-sectional study guided by the STROBE tool. The survey was conducted between October 2016 and May 2017 in the seven public reference services for assistance to people living with HIV in the City of Recife, State of Pernambuco.

\section{Population or sample; inclusion and exclusion criteria}

During the study period, 1,032 individuals with HIV and aged 60 years or older were registered at the State Health Secretariat and performing periodic follow-up in the selected services. Of these, after the sample calculation, 241 were included in the study. To determine the sample size, a prevalence of $50 \%$ was considered. Despite maximizing the sample size, we opted for this value because it has not yet been identified in the literature consensus on the magnitude of the event's prevalence under study. We determined the confidence level of $95 \%$ and the maximum acceptable error of $5 \%$. Also, and considering the fact of being a finite population, we used the Correction Factor for Finite Population for the final calculation of the sample. Thus, we included those aged 60 years or over (a condition that defines the elderly person, according to Law No. 8842/94, which deals with the National Elderly Policy); who were registered in the services up to 60 days before the start of the research; and who were using antiretroviral therapy for at least 30 days.

The sample's selection occurred initially by identifying the date of birth in the medical records of individuals who had an appointment for that day with an infectologist, psychologist, nutritionist, or nurse. After consultation, the individual was invited to participate in the research and, if accepted, the interview took place in a room provided by the service for this purpose.

\section{Study protocol}

We used a sociodemographic questionnaire to collect the data, previously prepared by the authors, which included the following variables: gender, age, income, education, time of diagnosis, religious affiliation, self-declared race/color, and marital status. It is worth noting that the minimum wage in force at the time of the beginning of the research was $\mathrm{R} \$ 937.00$ (nine hundred and thirty-seven reais), and schooling measured in years of study as follows: illiterate; 1 - 4 years; $5-8$ years; $9-11$ years and $\geq 11$ years. 
The HIV/Aids Target Quality of Life scale (HAT-Qol) was used to assess the quality of life. This instrument includes questions regarding the way the individual has felt in the last four weeks concerning some aspects: general function, sexual function, satisfaction with life, concern about medicines, financial concerns, acceptance of HIV, concerns about secrecy, health concerns, and confidence in the service/health professional who performs the follow-up. Each dimension has a total score ranging from zero (0) to one hundred (100), and the higher the score the better the quality of life in that area ${ }^{(13)}$.

The short version with 15 questions of the Yesavage Geriatric Depression Scale (EDG-15), specifically designed for use in the elderly population, was used to screen for depression. The original version has 30 questions focused on usual aspects of depression in this audience, such as motivation, cognitive complaints, and mood. The EDG-15 was built on items that are most related to the diagnosis of depression and because it is an easy-to-understand instrument, can be self-applied. The results range from 0 to 15 , are divided into 0 - 5 (regular), 6 -10 (mild depression), and 11 15 (severe depression), the latter being indicative of referral for psychological evaluation $^{(14)}$.

We applied the Satisfaction Scale with Life to assess satisfaction, which was built based on The Theory of Subjective Well-Being and validated. In its structure are contemplated five statements that are answered according to the level of agreement of the Individual: 1 (I totally disagree); 2 (I disagree); 3 (I disagree more or less); 4 (neither I agree nor I disagree); 5 (I agree more or less); 6 (I agree) and 7 (I totally agree). The final score may range from 5 (five) to 35 (thirty-five) points, and the result is divided into two categories: "satisfied with life" and "dissatisfied with life." Each of these is subdivided into three subcategories with their respective scores. The Satisfied with Life category includes results that may vary from 20 to 35 and is classified as follows: 20 -24 (average score for satisfied), 25 - 29 (high score for satisfied), and 30 - 35 (very satisfied). The Dissatisfied with Life category includes the following scores: 5 - 9 (very dissatisfied), 10 - 14 (dissatisfied), and $15-19$ (below the average for satisfaction) ${ }^{(15)}$.

We assessed functionality using the Barthel Index. It is a tool used to verify the functional ability in the direction of independence and the realization of self-care, mobility, locomotion, and eliminations, as these items are noted, based on the level of assistance required by a person for the implementation of the ten (10) items related to the Activities of Daily Living (ADLs): feeding, bathing, clothing, and personal hygiene, bowel elimination, urinary eliminations, and the use of the toilet, transfer from chair to bed, and vice versa, and walk, and walk up and down the stairs. These items are scored according to the individual's performance, with classification into independent (10 points), with some help (05 points), and dependent (0). The total score ranges from 0 to 100 , the higher the value of the sum of the scores, the more independent the individual is ${ }^{(16)}$.

\section{Analysis of results and statistics}

We saved the initial data in Excel spreadsheets, which were double-checked and validated by another researcher. Descriptive statistics were used for sociodemographic data, depression, life satisfaction, and functionality. For the quality of life, the scores of each dimension were calculated and their normality was verified by the Shapiro-Wilk Test. However, we have found no normality.

The Spearman nonparametric correlation test was used to determine the degree of correlation of the variables "depression, life satisfaction and functionality" with the HAT-Qol domains "general function, life satisfaction, health concerns, financial concerns, medication concerns, HIV acceptance, concern about secrecy, confidence in the professional and sexual function", since the variables did not present a normal distribution.

\section{RESULTS}

The sample ( $\mathrm{N}=241)$ was composed mostly of male individuals. As for marital status and schooling, singles and those who attended school for up to four years prevailed. There was a prevalence of men in the age group from 60 to 64 years, with 60 years being the minimum age and 82 the maximum found. The prevailing income was 1 to 2 minimum wages and the selfdeclared race and religion, Brown and Catholic, respectively. As for the time of diagnosis, individuals diagnosed 10 or 15 years ago prevailed (Table 1).

In the dimension "Satisfaction with Life," the majority of respondents considered themselves satisfied. Regarding "Depression," after applying the instrument for specific screening, we identified that more than half of the sample had no depressive symptoms. However, we identified participants with severe depression in an amount similar to those who considered themselves very dissatisfied with their lives. Regarding functionality, the sample, in almost its entirety, was classified as "functionally independent," and severe dependence was identified in only one individual. No individual had total dependence (Table 2).

In the assessment of the quality of life, the dimensions with the highest averages were: Medication concerns (86.35); health concerns (82.94); and acceptance of HIV (80.65). The lowest average were identified in the domains: concerns about secrecy (49.59) and sexual function (54.25).

When analyzing the degree of correlation between the HATQoL domains and measures of depression, life satisfaction and functionality, the degree of inverse correlation was observed in all HAT-QoL domains with depressive symptomatology, being a regular correlation in the following domains: General function, Life satisfaction, Health concerns, Financial concerns and Acceptance of HIV. In the other domains, there was a weak correlation. All these correlations are statistically significant (Table 3).

We identified a positive correlation in all HAT-Qol domains with life satisfaction, with a moderate correlation in the following domains: General function, Life satisfaction, Health concerns, Financial concerns, and Acceptance of HIV. In the others, the correlation was weak. The correlations were not statistically significant only in the areas of Concerns about secrecy and sexual function. Regarding functionality, we identified a statistically significant correlation in the following domains: General function, Satisfaction with life, Health concerns, and Medication concerns, and the degree of correlation between all these domains was weak. In the others, only correlations close to zero were observed (Table 3). 
Table 1 - Characterization of the sample according to sociodemographic data, Recife, State of Pernambuco, Brazil, 2020 ( $N=241)$

\begin{tabular}{|c|c|c|}
\hline \multirow{2}{*}{ Variables } & \multicolumn{2}{|c|}{ Total } \\
\hline & $\mathbf{n}$ & $\%$ \\
\hline \multicolumn{3}{|l|}{ Gender } \\
\hline Male & 151 & 62.7 \\
\hline Female & 90 & 37.3 \\
\hline \multicolumn{3}{|l|}{ Age (years) } \\
\hline $60|-| 64$ & 131 & 54.4 \\
\hline $65|-| 70$ & 81 & 33.6 \\
\hline$\geq 70$ & 29 & 12.0 \\
\hline \multicolumn{3}{|l|}{ Marital status } \\
\hline Single (a) & 83 & 34.4 \\
\hline Married & 74 & 30.7 \\
\hline Widow & 45 & 18.7 \\
\hline Separate & 39 & 16.2 \\
\hline \multicolumn{3}{|l|}{ Education (years) } \\
\hline Illiterate & 25 & 10.4 \\
\hline $1|-| 4$ & 69 & 28.6 \\
\hline $5-8$ & 59 & 24.5 \\
\hline $9-11$ & 56 & 23.2 \\
\hline$\geq 11$ & 32 & 13.3 \\
\hline \multicolumn{3}{|l|}{ Income* } \\
\hline No income & 15 & 6.2 \\
\hline$<1$ minimum wage & 27 & 11.2 \\
\hline $1|-| 2$ minimum wages & 134 & 55.6 \\
\hline $2,1 \mid-4$ minimum wages & 36 & 14.9 \\
\hline$>4$ minimum wages & 29 & 12.0 \\
\hline \multicolumn{3}{|l|}{ Self-Declared Race } \\
\hline White & 61 & 25.3 \\
\hline Black & 33 & 13.7 \\
\hline Brown & 147 & 61.0 \\
\hline \multicolumn{3}{|l|}{ Religious affiliation } \\
\hline Catholic & 125 & 51.9 \\
\hline Christian & 68 & 28.2 \\
\hline Other / Spiritist & 18 & 7.5 \\
\hline No declared religion & 30 & 12.4 \\
\hline \multicolumn{3}{|l|}{ Diagnosis time } \\
\hline$<5$ years & 38 & 15.8 \\
\hline $5 \mid-10$ & 43 & 17.8 \\
\hline $10 \mid-15$ & 77 & 32.0 \\
\hline $15 \mid-20$ & 53 & 22.0 \\
\hline$\geq 20$ & 30 & 12.4 \\
\hline
\end{tabular}

Note: * Minimum wage in force during the study period was $R \$ 937.00$ (nine hundred and thirty-seven reais)

Table 2 - Sample distribution according to Life satisfaction, Depression and Functionality, Recife, State of Pernambuco, Brazil, 2020 (N=241)

\begin{tabular}{lcc}
\hline Variables & Total \\
& n & $\%$ \\
\hline Life satisfaction & & \\
Satisfied with life & & \\
$\quad$ Very satisfied & 81 & 33.6 \\
$\quad$ High satisfaction score & 62 & 25.7 \\
$\quad$ Average satisfaction score & 46 & 19.1 \\
Dissatisfied with life & & \\
$\quad$ Below average satisfaction & 26 & 10.8 \\
$\quad$ Unsatisfied & 16 & 6.6 \\
$\quad$ Very dissatisfied & 10 & 4.1 \\
Depression & & \\
Normal & 162 & 67.2 \\
Mild depression & 67 & 27.8 \\
Severe depression & 12 & 5.0 \\
Functionality & & \\
Total dependence & 0 & 0.0 \\
Severe dependence & 1 & 0.4 \\
Moderate dependence & 15 & 6.2 \\
$\quad$ Very mild dependence & 22 & 9.1 \\
Independence & 203 & 84.2 \\
\hline
\end{tabular}

Table 3 - Correlation of HAT-QoL domains with Depression, Life satisfaction and Functionality of the study sample, Recife, State of Pernambuco, Brazil, $2020(\mathrm{~N}=241)$

\begin{tabular}{lccc}
\hline Domains & $\begin{array}{c}\text { Depression } \\
\mathbf{r}\end{array}$ & $\begin{array}{c}\text { Life } \\
\text { satisfaction } \\
\mathbf{r}\end{array}$ & $\begin{array}{c}\text { Functionality } \\
\mathbf{R}\end{array}$ \\
\hline HAT-QoL & & & \\
General function & $-.475^{* *}$ & $.384^{* *}$ & $.232^{* *}$ \\
Life satisfaction & $-.547^{* *}$ & $.452^{* *}$ & $.141^{*}$ \\
Health concerns & $-.493^{* *}$ & $.330^{* *}$ & $.217^{* *}$ \\
Financial concerns & $-.421^{* *}$ & $.464^{* *}$ & 0.124 \\
Medication concerns & $-.297^{* *}$ & $.231^{* *}$ & $.166^{* *}$ \\
Acceptance of HIV & $-.329^{* *}$ & $.331^{* *}$ & 0.007 \\
Concerns about secrecy & $-.181^{* *}$ & 0.089 & 0.077 \\
Trust in the professional & $-.133^{*}$ & $.128^{*}$ & -0.057 \\
Sexual function & $-.255^{* *}$ & 0.084 & 0.001 \\
\hline Note: ${ }^{*} p<0.05^{* *} p<0.01$. & & & \\
DISCUSSION & & &
\end{tabular}

Participants in this study can be classified as "young elderly" since they are between 60 and 79 years old ${ }^{(17)}$. The predominance of males follows the pattern of the National HIV profile since from the beginning of the epidemic to the present day, there is a greater number of men affected in virtually all age groups. In the State of Pernambuco, they only lose to women in the age groups of 1 to 4 years, 10 to 14 years, and 80 years or more ${ }^{(18)}$.

Two other results of this study resemble the national social profile. It is about the self-declared race and schooling. In these areas, there is a greater number of brown people with a lower degree of Education, which differs from the initial scenario of the epidemic, when HIV was more common among individuals with eight or more years of study ${ }^{(19)}$. We should also consider that the times in which the elderly in the study lived in the past are different times from the current ones and most likely going to school may have been influenced by social and economic factors of the time.

The time of diagnosis found in this study can be considered an example of the success of antiretroviral therapy, which is essential for the Prevention of opportunistic diseases ${ }^{(3)}$. Currently, there are several classes of antiretrovirals that, through combinations, formed what is known today as "Highly Active Antiretroviral Therapy $(\text { HAART })^{\prime \prime(20)}$. One of the benefits of HAART is the increase in life expectancy since that there is no interruption in treatment and a healthy lifestyle is adopted, and it can even reach an increase of up to 50 years in survival(3).

Although depression is a condition commonly experienced by people with $\mathrm{HIV}^{(21)}$, the results of this study did not show any depressive symptoms in more than half of the participants. We observed a similar result in the variable "Satisfaction with life," in which most individuals were satisfied. Well-being refers to the perception and evaluation that people have and make of their own lives as a subjective and multidimensional construct ${ }^{(22)}$.

Currently, although HIV infection is considered a chronic disease, capable, therefore, of interfering with the independence and autonomy of the elderly person ${ }^{(12)}$, the participants of this research were considered, almost in their entirety, as "independent" from the functional point of view, which means a good ability to administer and care for one's own life. Therefore, they can also be recognized as active seniors since they are independent and 
autonomous to carry out the activities inherent in everyday life, regardless of whether they have some "health problem" or not ${ }^{(23)}$.

When analyzing the correlation of the domains of quality of life with depression, we observed an inverse correlation, i.e., the higher the depressive symptomatology, the worse the quality of life. We noticed that the most intense correlations were with the domains "Satisfaction with life" and "Concern with Health," which we could already expect since depression causes mood changes ${ }^{(24)}$. There is, therefore, the existence of negative feelings, in addition to multiple somatic complaints, and also a differentiated perception of oneself, so that the individuals begin to see their problems as catastrophic ${ }^{(25)}$.

There are several risk factors for depression in old age, including smoking, body mass index above the recommended height, feeling of dissatisfaction with life, self-perceived poor health, low level of education, functional inability to perform basic and instrumental daily life activities, being retired, female gender ${ }^{(26-28)}$. Thus, factors such as difficulties in the affective-sexual relationship, marital conflicts, social exclusion, and the very stigma that permeates this disease can be added ${ }^{(21)}$.

In this perspective, the data of the present study prove that depression impairs all dimensions of the quality of life of the elderly person living with HIV. It is worth adding that, from the immune point of view, changes also occur ranging from the decrease in the action of natural killer cells and CD8 lymphocytes ${ }^{(29)}$ to the negative impact on the progression of the disease ${ }^{(30)}$. However, even though it is one of the most prevalent psychiatric disorders among people with HIV, it is believed that most cases are not diagnosed, nor treated correctly ${ }^{(31)}$.

Regarding the correlation between the domains of quality of life and the scale of satisfaction with life, we identified a positive correlation in all domains, which was an expected result. The Financial concern domain has the highest correlation, a primary factor for the quality of life since financial stability and the absence of concerns about monetary commitments generate a more positive perception related to life ${ }^{(32)}$.

This finding may be related to some topics of the Brazilian legislation that deals with the granting of retirement and welfare benefits. One of them, and also responsible for half of the pensions granted in Brazil, refers to the requirement to retire by age, which, during the study period, determined a minimum age of 65 years for men and 60 years for women residing in the urban area. Also, the continuous benefit (BPC) of the Organic Law of Social Assistance (LOAS) guarantees the receipt of a monthly minimum wage to people aged 65 years and over and who have an income of up to $1 / 4$ of the current minimum wage per person of the family group.
Regarding functionality, this presented a significant but weak correlation in four domains of quality of life. More than $80 \%$ of the sample reached the maximum score of the Barthel Index, which implies that the "ceiling effect" occurred, a fact that causes limitations in the capacity of the instrument in the discrimination of participants ${ }^{(33)}$. This effect occurs when the number of people with the highest score is more than $10 \%$ of the sample size ${ }^{(34)}$.

However, even if it is a weak significant correlation, we can confirm that there is a relationship between the quality of life and the functionality of the individuals. Thus, elderly people who are able to perform their daily activities with independence and autonomy have a better the quality of life when compared to those who have some limitation, because, in fact, quality of life in old age comprises aspects such as independence, autonomy, continuity of social roles, formal and informal support, environmental safety and health ${ }^{(35)}$.

\section{Limitations of the study}

The present study had as a limitation the transverse design, which does not allow the evaluation of a sample longitudinally. There is also a shortage of studies that evaluate the correlation between the variables studied, making comparisons difficult.

\section{Contributions to the fields of Nursing, Health or Public Policy}

The results found in this study may support strategies for nurses to act in Public Health since the encouragement of safe sexual practice should be one of the targets of primary health care for the elderly. An open space for discussing this topic with the elderly themselves, family members, and the health team can motivate the change of habits and enable intervention in the factors that compromise the individual's quality of life.

\section{CONCLUSION}

We identified that the quality of life of the elderly persons living with HIV can be impaired in all its dimensions by depression, while feeling satisfied with life can influence it positively, being the financial condition an essential factor for achieving satisfaction. Finally, we found a type of positive influence of functional capacity on the quality of life, but in lower intensity when compared to life satisfaction. We concluded that life satisfaction influences the quality of life more positively than functional capacity.

\section{FUNDING}

Fundação de Apoio à Pesquisa do Estado da Paraíba - FAPESQ.

\section{REFERENCES}

1. Pieri FM, Laurenti R. HIV/AIDS: Perfil epidemiológico de adultos internados em Hospital Universitário. Ciênc Cuid Saúde. 2012;11(supl):14452. https://doi.org/10.4025/cienccuidsaude.v11i5.17069

2. Ministério da Saúde (BR). Boletim epidemiológico AIDS-DST: 2016 [Internet]. 2016[cited 2020 Aug 25];V(1). 64 p. Available from: https:// www.far.fiocruz.br/wp-content/uploads/2017/12/boletim_2016_1_pdf_16375-1.pdf

3. UNAIDS. Prevention Gap Report [Internet]. 2016 [cited 2020 Aug 19]. 286 p. Available from: https://www.unaids.org/sites/default/files/ media_asset/2016-prevention-gap-report_en.pdf 
4. UNFPA. Situação da População Mundial [Internet]. 2020 [cited 2021 Jan 26]. 164 p. Available from: https://brazil.unfpa.org/sites/default/ files/pub-pdf/situacao_da_populacao_mundial_2020-unfpa.pdf

5. Organizaçao das Nações Unidas (ONU). Revision of World Population Prospects [Internet]. 2019 [cited 2021 Jan 26]. Available from: https:// population.un.org/wpp2019/

6. Ministério da Saúde (BR). Atenção à saúde da pessoa idosa e envelhecimento [Internet]. Brasília: MS; 2010[cited 2020 Aug 20]. 46 p. Available from: http://bvsms.saude.gov.br/bvs/publicacoes/atencao_saude_pessoa_idosa_envelhecimento_v12.pdf

7. Araújo KMST, Leal MCC, Marques APO, Silva SRA, Aguiar RB, Tavares MTDB. Avaliação da qualidade de vida de pessoas idosas com HIV assistidos em serviços de referência. Ciênc Saúde Colet. 2020;25(6):2009-16. https://doi.org/10.1590/1413-81232020256.20512018

8. UNAIDS. Índice de Estigma em relação às pessoas vivendo com HIV/AIDS: Brasil [Internet]. 2019 [cited 2021 Jan 26]. Available from: https:// unaids.org.br/wp-content/uploads/2020/01/Exec_Sum_ARTE_2_web.pdf

9. Silva AO, Loreto MDS, Mafra SCT. HIV na terceira idade: repercussões nos domínios da vida e funcionamento familiar. Rev Pauta. 2017;39(15):129-54. https://doi.org/10.12957/REP.2017.30380

10. Mendonça ETM, Araújo EC, Botelho EP, Polaro SHI, Gonçalves LHT. Experience of sexuality and HIV/Aids in the third age. Res Soc Develop. 2020;9(7):1-26. https://doi.org/10.33448/rsd-v9i7.4256

11. Caliari JS, Teles AS, Reis RK, Gir E. Fatores relacionados com a estigmatização percebida de pessoas vivendo com HIV. Rev Esc Enferm USP. 2017;51:e03248. https://doi.org/10.1590/s1980-220×2016046703248

12. Cruz GECP, Ramos LR. Limitações funcionais e incapacidades de idosos com síndrome de imunodeficiência adquirida. Acta Paul Enferm. 2015;28(5):488-93. https://doi.org/10.1590/1982-0194201500081

13. Soárez PC, Castela A, Abrão P, Holmes WC, Ciconelli RM. Tradução e validação de um questionário de avaliação de qualidade de vida em AIDS no Brasil. Rev Panam Salud Publica [Internet]. 2009 [cited 2020 Aug 16];25(1):69-76. Available from: http://www.scielosp.org/pdf/rpsp/v25n1/11.pdf

14. Silva VPO, Carneiro LV, Lucena WMA, Alixandre AL, Oliveira JS. Escala de depressão geriátrica como instrumento assistencial do enfermeiro no rastreio de sintomas depressivos em idosos institucionalizados. Braz J Develop[Internet]. 2020 [cited 2021 Jan 26];6(3):12166-77. https:// doi.org/10.34117/bjdv6n3-188

15. Silva WR, Ferrari EP, Vieira M, Melo G, Cardoso FL. Propriedades psicométricas da escala de satisfação com a vida no contexto esportivo brasileiro. Rev Bras Med Esporte. 2018;24(1). https://doi.org/10.1590/1517-869220182401172303

16. Minosso JSM, Amendola F, Alavarenga MRM, Oliveira MAC. Validação, no Brasil, do Índice de Barthel em idosos atendidos em ambulatórios. Acta Paul Enferm 2010;23(2):218-23. https://doi.org/10.1590/S0103-21002010000200011

17. Santos PM, Souza BC, Marinho A, Mazo GZ. Percepção de qualidade de vida entre idosos jovens e longevos praticantes de hidroginástica. Rev Bras Qual Vida 2013;5(1):1-11. https://doi.org/10.3895/S2175-08582013000100001

18. Secretaria de Saúde do Estado de Pernambuco. Secretaria Executiva de Vigilância em Saúde. Diretoria Geral de Controle de Doenças e Agravos. Programa estadual de IST/AIDS/HIV. Boletim Epidemiológico Vigilância HIV/AIDS - Pernambuco, 2016 [cited 2020 Aug 15]. 24 p. Available from: http://portal.saude.pe.gov.br/sites/portal.saude.pe.gov.br/files/boletim_hiv_aids_pe_2016.pdf

19. Silva J, Bunn K, Bertoni RF, Neves OA, Traebert J. Quality of life of people living with HIV. AIDS Care. 2013;25(1):71-6. https://doi.org/10.1080/ 09540121.2012 .686594

20. Nunes AA, Caliani LS, Nunes MS, Silva AS, Mello LM. Análise do perfil de pacientes com HIV/Aids hospitalizados após introdução da terapia antirretroviral (HAART). Ciênc Saúde Colet. 2015;20(10):3191-8. https://doi.org/10.1590/1413-812320152010.03062015

21. Reis RK, Haas VJ, Santos CB, Teles SA, Galvão MTG, Gir E. Sintomas de depressão e qualidade de vida de pessoas vivendo com HIV/aids. Rev Latino-Am Enfermagem [Internet]. 2011 [cited 2020 Aug 18];19(4):874-81. Available from: https://www.scielo.br/pdf/rlae/v19n4/pt_04.pdf

22. Albuquerque AS, Tróccoli BT. Desenvolvimento de uma escala de bem-estar subjetivo. Psicol Teor Pesqui. 2004;20(2);153-64. https://doi. org/10.1590/S0102-37722004000200008

23. Ferreira OGL, Maciel SC, Costa SMG, Silva AO, Moreira MASP. Envelhecimento ativo e sua relação com a independência funcional. Texto Contexto Enferm [Internet] 2012 [cited 2021 Jan 26];21(3):513-8. Available from: https://www.scielo.br/pdf/tce/v21n3/v21n3a04.pdf

24. Teston EF, Carreira L, Marcon SS. Sintomas depressivos em idosos: comparação entre residentes em condomínio específico para idoso e na comunidade. Rev Bras Enferm. 2014;67(3):450-6. https://doi.org/10.5935/0034-7167.20140060

25. Matias AGC, Fonsêca MA, Gomes MLF, Matos MAA. Indicadores de depressão em idosos e os diferentes métodos de rastreamento. Einstein. 2016;14(1):6-11. https://doi.org/10.1590/S1679-45082016AO3447

26. Bretanha AF, Facchini LA, Nunes BP, Munhoz TN, Tomasi E, Thumé E. Sintomas depressivos em idosos residentes em áreas de abrangência das unidades básicas de saúde da zona urbana de Bagé, RS. Rev Bras Epidemiol. 2015;18(1):1-12. https://doi. org/10.1590/1980-5497201500010001

27. Lopes NE, Librelotto RL, Souza GS, Irenio G, Alfredo CN. Screening for depressive symptoms in older adults in the Family Health Strategy, Porto Alegre, Brazil. Rev Saude Publica. 2014;48(3):368-77. https://doi.org/10.1590/S0034-8910.2014048004660

28. Choi GS, Shin YS, Kim JH, Choi SY, Lee SK, Nam YH, et al. Prevalence and risk factors for depression in Korean adult patients with asthma: is there a difference between elderly and non-elderly patients? J Korean Med Sci[Internet]. 2014 [cited 2021 Jan 26];29(12):1626-31. https:// doi.org/10.3346/jkms.2014.29.12.1626 
29. Vismari L, Alves GJ, Palermo-Neto J. Depressão, antidepressivos e sistema imune: um novo olhar sobre um velho problema. Rev Psiquiatr Clín[Internet]. 2008 [cited 2021 Jan 26];35(5):196-204. Available from: https://www.scielo.br/pdf/rpc/v35n5/a04v35n5.pdf

30. Cruess DG, Douglas SD, Pettito JM, Have TT, Gettes D, Dubé B, et al. Association of resolution of major depression with increased natural killer cell activity among HIV-seropositive women. Am J Psyquiatr. 2005;162:11. https://doi.org/10.1176/appi.ajp.162.11.2125

31. Coutinho MFC, O'Dwyer G, Frossard V. Tratamento antirretroviral: adesão e a influência da depressão em usuários com HIV/Aids atendidos na atenção primária. Saúde Debate [Internet]. 2018 [cited 2021 Jan 26];42(116):148-61. https://doi.org/10.1590/0103-1104201811612

32. Hagerty MR, Veenhoven R. Wealth and happiness revisited-growing national income does go with greater happiness. Soc Indic Res[Internet]. 2003 [cited 2020 Aug 20];64(1):1-27. Available from: http://www.jstor.org/stable/27527110

33. Mao H, Hsueh I, Tang P, Sheu C, Hsieh C. Analysis and comparison of the psychometric properties of three balance measures for stroke patients. Stroke. 2002;33(4):1022-7. https://doi.org/10.1161/01.STR.0000012516.63191.C5

34. Mchorney CA, Ware JEJR, Lu JF, Sherbourne RL, Donald C. The MOS 36-item short-form health survey (SF-36): III. tests of data quality, scaling assumptions, and reliability across diverse patient groups. Med Care. 1994;32(1):40-66. https://doi.org/10.1097/00005650-199401000-00004.

35. Rebelatto JR, Morelli JG. Fisioterapia geriátrica: a prática da assistência ao idoso. Manole; 2004. 540 p. 